\title{
Transdisciplinarity-A Bold Way into the Academic Future, from a European Medievalist Perspective and or the Rediscovery of Philology?
}

\begin{abstract}
Albrecht Classen (iD
Department of German Studies, University of Arizona, Tucson, AZ 85721, USA; aclassen@email.arizona.edu

Abstract: This essay examines the challenges and opportunities provided by transdisciplinarity from the point of view of medieval literature. This approach is situated within the universal framework of General Education or Liberal Arts, which in turn derives its essential inspiration from medieval and ancient learning. On the one hand, the various recent efforts to work transdisciplinarily are outlined and discussed; on the other, a selection of medieval narratives and one modern German novel plus one eighteenth-century ode are examined to illustrate how a transdisciplinary approach could work productively in order to innovate the principles of the modern university or all academic learning, putting the necessary tools of twenty-first century epistemology into the hands of the new generation. The specific angle pursued here consists of drawing from the world of medieval philosophy and literature as a new launching pad for future endeavors.
\end{abstract}

check for

updates

Citation: Classen, Albrecht. 2021. Transdisciplinarity-A Bold Way into the Academic Future, from a European Medievalist Perspective and or the Rediscovery of Philology? Humanities 10: 96. https://doi.org/ 10.3390/h10030096

Received: 8 June 2021

Accepted: 3 August 2021

Published: 10 August 2021

Publisher's Note: MDPI stays neutral with regard to jurisdictional claims in published maps and institutional affiliations.

Copyright: (C) 2021 by the author. Licensee MDPI, Basel, Switzerland. This article is an open access article distributed under the terms and conditions of the Creative Commons Attribution (CC BY) license (https:/ / creativecommons.org/licenses/by/ $4.0 /)$.
Keywords: transdisciplinarity; general education; liberal arts; Wolfram von Eschenbach; Gottfried von Strassburg; Dante Alighieri; mysticism; Rudolf von Ems; Boccaccio; Hrotsvit of Gandersheim; Herrad of Hohenburg; Sir Gawain and the Green Knight; Fortunatus; Hermann Hesse; Friedrich Gottlieb Klopstock

\section{Theoretical Introduction}

In theory, much has already been said regarding transdisciplinarity in recent years. It appears to be a highly exciting new approach in academic research developing bridges between even the most distant fields of investigation in order to reach a higher level of hermeneutics and epistemology, certainly highly desirable for the twenty-first century thirst for new synergies and innovative research. Instead of anxiously observing the traditional disciplinary boundaries in order to protect one's own scholarly territory, we are suddenly hearing calls to break down those long-cherished walls between departments and to restructure the entire university system based on completely different concepts, basically a call to return to the ideas as they had been originally conceived by such major philosophers, educators, and founders as Friedrich Schleiermacher (1768-1834), Wilhelm von Humboldt (1767-1835, Berlin University), Thomas Jefferson (1743-1826, University of Virginia), and Daniel Coit Gilman (1831-1908; Harvard University). We should not underestimate their contributions already then to the formation of the Liberal Arts, General Education (as we call it today) as a university study topic, and academic freedom at large, and we should consider their insights highly innovative and productive also today. Their pedagogical ideals launched a whole new world of advanced academic learning and research, deeply predicated on transdisciplinarity (though without the use of that word then), and since we are marching toward a new paradigm at the present time, our educational system once again requires innovation, open perspectives, and, to highlight the key aspect once again, transdisciplinary methods and approaches.

At the same time, we should not forget that these scholars in turn had drawn extensively on medieval concepts of advanced education predicated on the trivium (grammar, logic, and rhetoric) and the quadrivium (geometry, mathematics, astronomy, and music) 
(Wagner 1983; Grafton and Jardine 1987; Bod 2014; Tubbs 2014; Zakaria 2015), as developed first by Martianus Capella (early fourth century: De nuptiis Philologiae et Mercurii, or: "On the Marriage of Philology and Mercury") and Boethius (d. ca. 525: De consolatione philosophiae). Departmental or disciplinary boundaries have obviously been the result of academic exigencies conforming to bureaucratic principles in modern times since the second half of the twentieth century, but they are not necessarily beneficial to the exploration of new perspectives, materials, data, and images nor are they contributing to the improvement of academic teaching and research (Rousseau et al. 2018; Von Sass 2019; Bołtuć 2021).

\section{Challenges and Promises}

As we will observe, transdisciplinarity promises much invigoration, new synergies, and innovative perspectives if realized in a delicate and exploratory balancing act, but Medieval Studies has pursued such an open-minded, integrative methodology for a very long time already and might thus be recognized as a forerunner of transdisciplinary humanities at large (https: / / www.crl.edu/collections / topics / medieval-studies (accessed on 2 August 2021); Classen 2010; Classen 2020c; for an extensive list of Medieval Studies centers, see also the useful list: https:/ / en.wikipedia.org/wiki/Medieval_studies\#: :text=Medieval\%20 studies $\% 20$ is $\% 20$ the $\% 20$ academic $\% 20$ interdisciplinary $\% 20$ study $\% 20$ of $\% 20$ the $\% 20$ Middle $\%$ 20Ages (accessed on 2 August 2021)). Nevertheless, for far too long, medievalists have also been forced to accept disciplinary boundaries for professional, mostly pedagogical reasons, meaning that Chaucer was taught in the English Department, Dante in the Italian Department, Wolfram von Eschenbach in the German Department, and so forth, always based on the argument that linguistic criteria necessitated such decisions. We certainly want to ensure that our students become familiar with the essential tools of their discipline, such as Middle English, Middle High German, or Medieval Italian, but in a more global context, the primary aim can only be to make those famous medieval narratives available for the new generation. The transdisciplinary approach would then invite the students/readers to consider global issues such as honor, love, death, God, the meaning of life, values, ethics, and ideals in a variety of texts, but then also within the field of pre-modern art, architecture, philosophy, religion, anthropology, economics, and political sciences, etc. (pp. XV-XXIII in Classen 2010).

However, as we have learned to realize in the last few decades, the study of the history of mentality, of the history of emotions, or the history of everyday life must by default go beyond such narrow academic strictures. Hence, the subsequent reflections are intended both as a wake-up call and as an appeal to explore how we might be able to reform the humanities and to connect them, maybe as the central core discipline, once again with the sciences, business, social and behavioral sciences, etc. (Lazzeretti et al. 2019).

After all, what purpose does research in whatever field serve, if not the improvement of life here on earth? In human terms, we aim for understanding, illumination, happiness, and health, trying to establish meaning and relevance, whether from a sociological, economic, political, religious-spiritual, physical, cultural, personal, or individual perspective. However, we also face the emergence of artificial intelligence as the basis of future trans-humanities, as Piotr Bołtuć outlines in his contribution to this volume.

On the surface, ethics and morality might not be of primary importance for the actual work in the sciences or in law, but all research must be based on integrity, truth, honesty, social responsibility, transparency, legality, and accountability in order to establish itself as acceptable for humanity at large (Shamoo and Resnik 2015). Significantly, the critical principles guiding the sciences, falsification and verification, prove to be the same by which humanities scholars are operating. The various partners certainly operate with different materials (literature and the arts versus physical material, political structures, economic conditions, radio signals, etc.), but the fundamental criteria that make research possible and meaningful in the first place are the same across the board. 


\section{Science and Humanities}

At first sight, it seems almost natural to pursue such transdisciplinarity further as an innovative approach because it is already happening in the natural sciences quite often and rather productively (microbiology and chemistry, physics and meteorology, optics and mathematics, etc.). New research clusters are forming currently, and so are new disciplines, such as medical humanities, integrative medicine, or biomedicine, which all have agreed that a more humanist approach to healing has proven to be highly effective. ${ }^{1}$ We cannot yet predict what the outcome of such academic experiments might be, but we must reflect on them now in order to be prepared for the ongoing paradigm shift and to be aware of the constructive and also deconstructive results and effects. As Choi and Pakhave (2006) have defined transdisciplinarity,

Transdisciplinarity integrates the natural, social and health sciences in a humanities context, and transcends their traditional boundaries. The objectives of multiple disciplinary approaches are to resolve real world or complex problems, to provide different perspectives on problems, to create comprehensive research questions, to develop consensus clinical definitions and guidelines, and to provide comprehensive health services. Multiple disciplinary teamwork has both benefits and drawbacks.

It seems to be quite natural that the efforts to work transdisciplinarily emerged primarily in the field of medicine because its study object is the human body with its almost infinite problems, illnesses, sicknesses, failures, etc. As we know for sure, however, human life is not determined by a simple binary opposition of the body versus the mind/soul. Instead, healing or health can only be achieved if the binary approach is put aside to make room for a complex, integrative, and holistic method, which includes aesthetics, ethics, morality, and value ideals (Hamilton 2008).

We are social beings, predicated on personal contacts, intellectual exchanges, and individual enjoyments. The experience of love is as much of central importance as are food and drink. We need answers regarding the meaning of death and the afterlife, and yet do not find them through any of the hard sciences. Cultural and historical studies taking the mental aspects into consideration have already confirmed this important observation for quite some time by now (Classen 2014). But how would the sciences and the humanities collaborate more intimately? The time has thus now come to investigate what transdisciplinarity might mean for academia at large and the humanities in particular.

The first task at hand would be to consider transdisciplinary work within the humanities. To what extent would it be possible for disciplines such as psychology and German studies, or astronomy and music, to join forces? Have not recent studies by Richard Koenigberg demonstrated that psychological interpretations of historical events, including the First and Second World War, the Holocaust, the Holodomor, and other genocides, offer far-reaching and relevant insights that shed light also on current conditions (Koenigberg n.d.)? How can a journal such as Humanities thrive on a transdisciplinary foundation and yet still remain focused on what really constitutes this field, globally defined as the study of human ideas and their expressions in literary, artistic, or philosophical form, while integrating science and other related fields (anthropology, geology, sociology, ecology, or economy)? (Classen 2011). Traditionally, history and any of the common humanities subject matters (French, German, Italian, Arabic, Chinese, etc.) have faced fairly insignificant difficulties in collaborating with each other, but there have also been considerable pitfalls and challenges involved because the individual faculties have been placed in all kinds of colleges or schools, depending on purely administrative criteria.

\section{The Study of Literature and Life through Transdisciplinarity} The Cavalry Is Coming!

By necessity, this section has to be general and inclusive so that we can recognize the global relevance of the arguments to be developed further below. Humanity has always faced many of the same concerns, issues, or problems for the individual and the collective, 
such as the search for freedom, constructive communication, love, the quest for God, the response to death, heroism, honor, ethics, morality, and so forth. As difficult as it might be to overcome the linguistic and cultural barriers, just so insightful and productive this kind of transdisciplinarity promises to be. Heroic epic poems in Old Norse, Middle High German, Old English, Ancient Persian, Medieval Arabic, etc., have always served well altogether to address fundamental issues in human life, and the more perspectives can be bundled together, the more complex our understanding of the central issues in human life, such as facing existential threats, will become. Studying the quest for and the effort to maintain individual freedom by way of drawing from medieval Swedish, German, Spanish, Arabic, or Japanese sources can only expose ever more relevant features and concepts of the same critical issues that matter centrally for us today as well (Classen 2021a).

Of course, it is an easy act by the academic administrations to merge various departments in order to save money-if mergers actually achieve that goal!- but a large task for the teachers and researchers on the ground to translate the abstract notion of the desired transdisciplinarity into reality. There are, after all, many different concepts closely related, and yet not similar enough, such as cross-, multi-, inter-, and transdisciplines (Refsum Jensenius 2012).

Even efforts within the core of the humanities to pursue a transdisciplinary perspective face serious challenges. How would Russian and Slavic collaborate effectively with German studies? Can Latin American studies and East Asian studies find enough common ground to forge ahead with new research based on such diverse cultural backgrounds? Why are philosophy and english mostly separated and housed in different colleges? Would it not make perfect sense to have history and French or Italian coordinate their efforts? How could we reasonably argue that music and German studies belong to completely separate academic units, when much of Classical and Romantic but also atonal music was created by German-language composers and when many libretti, for instance, were written in that language (or Italian, French, etc.)? Sociology, mostly founded by German scholars such as Max Weber (1864-1920) and deeply influenced until today by contemporary thinkers such as Jürgen Habermas (1929-), is mostly situated in social and behavioral science but not in the humanities.

We are currently facing increased efforts by the government, the educational boards, and university administrators to corporatize higher education, which transforms all academic principles, replacing their humanist and scientific ideals with capitalistic concepts of input and output, irrespective of scholarly standards, observing monetary efficiency as the only acceptable business model for the university (Clay 2008). For most scholars in the humanities, this has catastrophic consequences because this field is not producing results that can be translated directly into economic products. Instead, the humanities cost money, but this is the same as with all solid school systems and should not be regarded as an undue burden for society at large. It is an obligation by the collective and not a privilege for the few. Education is, after all, an investment in the future and guarantees a long-term yield through the young generation preparing them for their own challenges.

This change in the pragmatic approaches has already been discussed from many sides, so it does no longer surprise us because financial criteria continuously gain in preponderance since governments worldwide demonstrate less and less interest in supporting education at large (K-16) as a public good (Donoghue 2008; reviewed by Stimpson 2009; Côté and Allahar 2020). The public good, however, is of the highest value, guaranteeing the survival of the human race, and this not only on the basic material level but also in terms of human culture and human values.

What government, however, would listen to those ideals today? These are political concerns deeply affecting the post-modern academy, and they are of great significance in many parts of our world wherever there are universities and institutions of higher learning. The question that I thus address really pertains to the relevance of sophisticated and advanced learning predicated on intellectual freedom, creativity, and open-mindedness within a global context (Holmes and Standen 2018; Classen, forthcoming). 


\section{Transdisciplinarity and General Education}

Amidst all of that turmoil, transdisciplinarity enters as an intriguing new player, and we are called upon, especially in the humanities, to consider the meaning of this model, weighing and balancing its advantages and disadvantages. Javier Collado Ruano offers this useful definition:

Transdisciplinarity represents the capable germ to promote an endogenous development of the evolutionary spirit of internal critical consciousness, where religion and science are complementary. Respect, solidarity and cooperation should be global standards for the entire human development with no boundaries. This requires a radical change in the ontological models of sustainable development, global education and world-society. We must rely on the recognition of a plurality of models, cultures and socio-economical diversification. As well as biodiversity is the way for the emergence of new species, cultural diversity represents the creative potential of world-society. (Collado Ruano 2013; cf. also Dravet et al. 2020)

In many respects, at least within the North American academic universe, by way of general education programs, as an inheritance of the traditional (medieval, and the Humboldtian) liberal arts concepts, transdisciplinarity has already entered the picture of the academic discourse for several decades. Courses for our freshmen and sophomores tend to be quite wide-ranging, covering many different aspects relevant to one specific topic, drawing from a range of sources that are no longer based just on one language or oneculture. Moreover, general education also entails the inclusion of relevant material covering not just a century, but a millennium, embracing not only one country, but a continent, or at least a whole culture with its plethora of facets. Linguistic hurdles certainly exist, but by means of decent translations they can be overcome in the name of transdisciplinarity, which in turn is predicated on collaboration and broadly conceived communication across the board. Of course, we need specialists trained in the individual languages who can guarantee the accuracy of translations, and they thus become crucial tools in the effort to establish transdisciplinarity at large.

At my own home university, the University of Arizona, the fundamental tenet of general education says it all:

The University-wide General Education Curriculum helps students attain the fundamental skills and broad base of knowledge that all college-educated adults must have, whatever their specific areas of concentration (i.e., the major and minor). The experiences of General Education encourage students to develop a critical and inquiring attitude, an appreciation of the interdisciplinary nature of subject areas, acceptance of persons of different backgrounds or values, and a deepened sense of self. The goal of General Education is to prepare students to respond more fully and effectively to an increasingly complex and ambiguous world. (https: / / catalog.arizona.edu/policy / general-education-curriculumspring-2022; accessed on 2 August 2021).

Whether this also leads to transdisciplinarity, whether the respective instructors are trained enough to go far beyond their own academic discipline in order to meet those expectations, and whether there is truly an awareness of how to embed specialized materials or texts into a wider discourse involving multiple disciplines would have to be decided case by case. However, the goal itself is unmistakably clear and can only be supported if we approach it sagaciously and collaboratively.

We could probably find countless parallel statements published by general education programs at any kind of college or university in North America all struggling to come to terms with the new challenges (e.g., University of Washington, Seattle: https://www.washington.edu/uaa/advising/degree-overview/general-education/ accessed on 2 August 2021; University of Michigan: https://lsa.umich.edu/advising/ understand-degree-options/bgs.html; accessed on 2 August 2021). In other words, trans- 
disciplinarity is already being practiced at various institutions of higher learning, even if without this theoretical jargon. However, we should also not ignore many understandable fears. There is, after all, the danger constantly lurking in the theoretical background that we might throw out the proverbial baby with the bath water. If, for instance, the study of Old English heroic poetry (Beowulf) or of Chaucer's Canterbury Tales might be abandoned because it prevents a more transdisciplinary teaching method, the price for innovation would then be too high, and it would, in fact, be short-sighted and self-destructive.

Of course, today we face, so it seems, a new set of issues of central concern in the humanities, as reflected by world literature, such as global migration, gender identity, racism, and environmental problems (Abba and Onyemachi 2020; Mallesh Reddy et al. 2021). Naturally, those issues need to be addressed from many different perspectives and academic disciplines, bringing together both scientists and economists, anthropologists and literary scholars.

Most intriguingly, as a growing number of medievalists has recently demonstrated, medieval voices can also serve exceedingly well to gain some of the necessary and relevant epistemological tools insofar as they address the very same issues concerning us today though perceived through different lenses. This is poignantly illustrated by the contributors to Reading the Natural World in the Middle Ages and Renaissance, edited by Willard (2020), who summarizes the results of the collective efforts of his contributors as follows:

The environment-together with ecology and other aspects of the way people see their world-has become a major focus of pre-modern studies. The thirteen contributions in this volume discuss topics across the millennium in Europe from the late $600 \mathrm{~s}$ to the early $1600 \mathrm{~s}$. They introduce applications to older texts, art works, and ideas made possible by relatively new fields of discourse such as animal studies, ecotheology, and Material Engagement Theory. From studies of medieval land charters and epics to the canticles sung in churches, the encyclopedic natural histories compiled for the learned, the hunting parks described and illustrated for the aristocracy, chronicles from the New World, classical paintings from the Old World, and the plays of Shakespeare, the authors engage with the human responses to nature in times when it touched their lives more intimately than it does for people today, even though this contact raised concerns that are still very much alive today. (Willard 2020; quote from: http: //www.brepols.net/Pages/ShowProduct.aspx?prod_id=IS-9782503590448-1; accessed on 2 August 2021)

In particular, however, as I will argue, the study of the Middle Ages lends itself particularly well to transdisciplinary methods, sometimes with quite surprisingly insightful and productive results. Unfortunately, however, the number of professorships in medieval English literature is shrinking across the board, and there is no doubt that pre-modern studies do not receive all the support they would deserve and need at universities across North America (https://academicjobs.wikia.org/wiki/Medieval_2019-2020; accessed on 2 August 2021). At my own university in Tucson, AZ, the only departments that still have a faculty member dedicated to the Middle Ages are History, Italian Studies, and German Studies (English has not had a Chaucerian for decades and French has not had a medievalist as far as I can remember!). However, that is not the current issue here, even though it certainly would have to be addressed urgently in a larger context since it constitutes a real crisis and undermines innovative efforts at transdisciplinary research (Classen 2019, 2020b).

However, there are already innovative efforts and steps in the right direction. As has recently been demonstrated by a British collaborative team, the transdisciplinary collaboration of a medical researcher and a scholar in Old English focusing together on an early medieval recipe book, Bald's Leechbook (tenth century), has yielded the discovery of a new method to combat a disease, that is, to "kill one of the most common causes of eye infections, the bacterium Staphylococcus aureus. More significantly, Bald's eyesalve can kill a range of antibiotic-resistant bacteria" (Harrison and Connelly 2020, p. 113). As 
Harrison and Connelly conclude: "Analysing and understanding medieval medicine and how it was practiced will not just provide a window into the medieval mind. It could ultimately enhance ethnopharmacological research and-potentially-open new routes to drug discovery. To bring to fruition nascent work in this area, increased interdisciplinary participation and greater allocation of resources to arts/science collaborations that currently fall through the cracks of traditional disciplinary funding will be essential" (p. 133).

\section{Transdisciplinarity as an Avatar of Traditional Medieval Philology}

The idea of transdisciplinarity has already been promoted for a long time, both in pragmatic and theoretical terms, though not under that label. Ernst Robert Curtius (18861956) was a major proponent of studying the pre-modern world through a very wide lens, incorporating most of Latin-speaking Europe from late classical antiquity to the eighteenth and nineteenth centuries (Curtius [1948] 1990; cf. Classen 1998). As he already noted decades ago, a particularist view of European history or literature can only mislead or blind us, since the medieval continent was, despite innumerable differences here and there, still a fairly consistent, if not holistic, cultural entity, with Christianity and Latin culture providing the overarching framework both in the far north and the far south, in western Ireland and in eastern Lithuania.

Both the antique-Mediterranean and the modern western world belong to and shape the same picture from which all contemporary literary and cultural studies have drawn from until today (Curtius [1948] 1990, p. 10). Other great scholars also embraced this pan-European perspective, such as Leo Spitzer (1887-1960), Arnold J. Toynbee (1889-1975), and Erich Auerbach (1892-1957), offering profound insights into the larger context of the pre-modern world. Karl Bertau (1927-2015) deserves credit for his efforts to incorporate art history and history into his examination of medieval German and European literature. Many other names should be mentioned here (for biographical sketches of some of major scholars, see Classen 2010; Classen, ed. 2015, Handbook of Medieval Culture), but may it suffice for now to observe that the practice of transdisciplinarity has already been heavily at work for almost hundred years, though under different names.

In fact, Medieval Studies, as a research area as it is emerging at the current moment, increasingly demonstrates its extensive openness toward a transdisciplinary approach. Particularly, very recent scholars have impressively endeavored to coordinate their efforts with scientists in fields such as meteorology, climate research, dendrochronology, archaeology, art history, and anthropology, along with medical historians, art and music historians, and researchers in the areas of foodstuff, consumption, digestion, etc. After all, when we study such famous authors as Marie de France, Chrétien de Troyes, Hartmann von Aue, Wolfram von Eschenbach, Dante Alighieri, Juan Ruiz, Boccaccio, Geoffrey Chaucer, Johann von Tepl, and Heinrich Kaufringer, or the various poets of the Icelandic Sagas, we are not only dealing with fictional texts but with literary mirrors of lived reality, though fractured through the imaginary lens, as modern critics have noted repeatedly (Vargas Llosa 1990; Eco 1993).

To make sense of those literary documents, we have available, of course, our usual hermeneutic instruments and tools of our trade in the humanities. At the same time, all poets have talked about their own lives, both in spiritual and material terms. Hence, we need to understand many different aspects alluded to, implied, referenced, or integrated, such as cosmology, spirituality, medicine, architecture, food stuffs, textiles, mathematics, horsemanship, farming, sea faring, communication and linguistics, etc. Naturally, fiction is, as the word entails, imaginary and fictional, but there is no imagination without some material foundation from which it can grow. Thus, each one of the world's great novels, plays, poems, essays, etc., really requires a critical approach from many different perspectives, informed by a wide range of expertise, if it is to be examined thoroughly and extensively. 


\section{Wolfram von Eschenbach}

For instance, in Wolfram von Eschenbach's Parzival (ca. 1205), a famous grail romance, we encounter a true plethora of scientific, medical, astronomical, and linguistic elements addressed by the poet (von Eschenbach 1998, 2006). The narrator relates, first of all, much about medieval knighthood, chivalry, Arthurian kingship, and contemporary material culture (tents, horses, clothing, weapons, armor, hunting, castles, etc.). However, we also gain deep insights into the perception of nature, the symbolic role of the forest and of rivers, the sudden appearance of snow, and winter. There are ironic references to merchants and their goods; we learn about new medical procedures and herbs to heal a wounded person (Gawan episodes). Magic and music also matter critically, and so do optics (medieval telescope or long-distance mirror), fashion, astronomy/astrology, and religion.

Granted, Wolfram scholarship has progressed tremendously over the last two hundred years, but until today, most researchers of this poet are trained Germanists and have not yet been joined by other scholars or scientists, although transdisciplinary approaches would open valuable perspectives, such as environmental concerns (Classen 2020e, 2020f). As Groos (1995), however, has already indicated, the extent to which we would need to understand the historical-medical, linguistic, and liturgical-religious background of this great romance to do full justice of its message (cf. also Murphy 2006).

\section{Rudolf von Ems}

Late medieval literature witnessed the considerable growth of interest in merchants and their trade, which was perhaps best expressed in Rudolf von Ems's Der guote Gêrhart (ca. 1220), in which a Cologne merchant operates as the protagonist who makes good businesses in the eastern Mediterranean and even further east but then returns via the western Mediterranean, driven by a storm to Morocco (Rudolf von Ems 2016). There, he encounters a noble-minded Muslim castellan, Stranmûr, and both men immediately strike up a friendship based on their shared ethical and cultural values. This also leads to a most unusual barter between them; Stranmûr happens to hold a Norwegian princess, her maids, and a number of English lords as his captives because their ship had landed in his harbor by accident. He would like to obtain ransom for them, but both England and Norway are too far away from his territory, so he needs this German merchant to help him carry out the desired transaction vicariously.

Eventually, Gêrhart hands over all of his wares and is then given in return the prisoners, for whom a large amount of money would be paid by their families back in Europe. Both men are completely convinced that this constitutes a great business for each side, but Gêrhart eventually demonstrates his truly noble character, allowing the English princes to return home without any payment, while he keeps the princess with him in Cologne, waiting in vain for her father to come forward and offering the ransom money The romance, however, concludes happily because her fiancé, the English prince Willehalm, appears unexpectedly, having survived his shipwreck off the coast of Norway, and Gêrhart immediately helps him to marry his beloved (Classen 2018b).

Recently, medieval historians have begun to explore more intensively the issues of slavery and piracy in the Mediterranean during the late Middle Ages, emphasizing that slavery never fully disappeared and actually grew considerably in the fourteenth and fifteenth centuries (Barker 2019; Mas i Forners 2005). If we were to combine the literary accounts with the numerous archival documents reflecting on the actual institution of slavery, we would suddenly face an intriguing opportunity to also explore this topic from a transdisciplinary perspective, with the literary analysis contributing to the historical investigations, and both supported by economic data concerning the trade in human beings both in Islamic and Christian harbors and markets, for instance. The surprising result would be that, for instance, Icelandic scholars would find a productive collaboration with experts in Africana Studies, and medievalists would recognize the great need to learn from their colleagues in Early Modern History focused on the Atlantic trade with slaves. Finally, 
medieval and early modern perspectives on this issue would thereby become critically important for the analysis of modern-day slavery in global terms (Classen 2021a).

By the same token, we could take the additional step and examine ship building types and economic aspects of trade in the medieval Mediterranean and consider in that context how much the world north of the Alps was also involved in the economic markets in southern Europe (Horden and Purcell 2000, 2020). The literary text could thus serve as a fictional mirror of economic conditions as projected by this thirteenth-century German poet who lived far away from the Mediterranean and yet incorporated significant comments on global trade, captivity, and slaves into his romance.

\section{Boccaccio}

Another significant example would be Boccaccio's Decameron (ca. 1350), where we hear much about a large variety of situations in the lives of people from all walks of life, including kings and queens, urban citizens, monks and nuns, simple country people, tricksters, prostitutes, craftsmen, and students. The number of critical interpretations is legion by now, and yet the high literary quality of this anthology of tales held together by a famous narrative frame finds its confirmation in the ever-ongoing research, which could also be enriched through a transdisciplinary approach (Boccaccio [1972] 1995). After all, the poet offers much cited comments on the Black Death as it raged in Florence in 1347-1349 and later reflects on the helplessness of the medical doctors in that situation, refers to the economic situation of the landed gentry with its luxurious estates outside of the city, discusses monasteries and the ordinary lives of monks and nuns-often from a highly satirical perspective, and remarks on the conditions of students, peasants, urban ladies, and refers to the numerous mercantile activities commonly carried out at that time (Aberth 2011, pp. 46-48).

Some of the stories mirror astounding examples of tolerance toward Jews and Muslims (Classen 2018c; Classen 2020d), whereas others are deeply drenched in misogyny. To make good sense out of this complex and highly influential collection of tales and their frame narrative, we ought to rely on a broad range of methodologies and disciplinary approaches that would extend well beyond just Italian literary studies.

Particularly the question concerning the history of pandemics has attracted various researchers in the field of virology and medicine at large to the study of Boccaccio's Decameron, particularly because it probably offers the most explicit discussion of the phenomena of the Black Death (Bauch and Schenk 2020). In order to understand the phenomenon of death as it was perceived in the late Middle Ages through the lens of art history, we would again be well-advised to consult with experts in that field, though literary scholars have also engaged with the relevant art works (Jost 2016). Death in itself, whether viewed through medical, historical, religious, art-historical, or literary lenses, requires a highly transdisciplinary approach, as Romedio Schmitz-Esser (2014) has recently demonstrated in his monumental study on the medieval corpse, Engl. trans. (Schmitz-Esser 2020).

What could a transdisciplinary methodology achieve in this case or with regard to literature at large? Would medical research profit from those medieval insights? Certainly not immediately, but Boccaccio provided significant impressions of the symptoms of the Black Death as experienced in the fourteenth century, and he illustrated through his literary treatment the way people responded, the fear they felt, and what strategies they pursued to escape the devastating pandemic at that time.

As recent investigations by a group of scholars have indicated, we are now able to trace more accurately how the Black Death migrated from Mongolia across the Himalayas down to the Indian subcontinent and from there made its way to the Black Sea, which then became the launching pad for its incursion into Europe (Green 2015). Despite the fictional framework of the Decameron, Boccaccio certainly provided a unique literary approach to the phenomenon itself as it was experienced in Florence and elsewhere and showed thereby how people at his time responded, when they had the resources available, relying on flight, 
storytelling, and deep reflections on the meaning of life itself in all of his humor and sorrow, which thus can illustrate further the impact of a pandemic on human society.

\section{Environmental Studies, Transdisciplinarity, and Literature}

Most recently, scholars have embarked on the ambitious project of studying environmental issues both from a scientific and a humanist perspective and have focused also on medieval conditions (Jones et al. 2020). Undoubtedly, the current global warming represents an unprecedented situation in all of earth history, but natural catastrophes and extreme weather patterns with resulting famine and poverty have always accompanied human history, threatening people's existence. Without denying the extreme problems the world is facing in the twenty-first century, we can certainly acknowledge that meteorologists and climate researchers can profit from and must actually rely closely on historical data in order to understand long-term developments and processes, the consequences of which often become noticeable only decades if not centuries later (i.e., consequences for forests, desertifications, floodings, etc.) (Aberth 2013; Camenisch 2015; Campbell 2010, 2016; Nardizzi and Werth 2019; Johns-Putra 2019; Warren 2021).

Unfortunately, at the current moment, the two partners in the academic approach to environmental issues, science and the humanities, often tend merely to stand next to each other, without engaging with the same issues together interactively. The reasons are quite obvious because, for instance, dendrochronology and Middle High German literature are not part and parcel of the same scientific discourse or community. However, while the first research field is focused on establishing hard data concerning the age of wood, the latter endeavors to reflect on the emotional, human side in its reaction to plants, trees, and forests. The future of transdisciplinarity still remains obscure to us, but at least we find today research papers by scientists and humanists already right next to each other in the same volume (Mallesh Reddy et al. 2021; Bennassar 1996; Jankrift 2003; Fouquet and Zeilinger 2011).

One of the critical issues with transdisciplinarity rests in the question of what the various types of data collected by one group of scholars/scientists can achieve hermeneutically for the respective other fields of research. The example of marine biology proves to be drastic and hence illustrative, especially if we draw from literary reflections on the current or past conditions of the world's oceans. However, data collection by itself is not the ultimate or only goal in the sciences either. Instead, the critical concern focuses, of course, on the analysis/interpretation of those data, which actually emerges as very parallel to the work performed by the scholars in the humanities. While the scientist draws those data from material elements, whether chemical compounds or light rays in space, the literary scholar investigates texts, above all, and attempts to isolate smaller and smaller details within the narrative in order to comprehend the overall structure and to penetrate more deeply into the hidden messages or ideals.

To stick to marine biology, while the scientists examine the conditions of the oceans at large, the humanist would then use those data to study how those people affected by global warming of the oceans have responded or would in the future (cf. the contributions to Jones et al. 2020). At the same time, past comments about the sea and its relationship with people as expressed in literary texts would support the critical investigation of what that large body of water has to say about and with people. We all live, after all, in a holistic world, symbiotically connected with all aspects of nature, so all our efforts contribute to the weaving of the same tapestry but using a vast variety of threads.

The focus generally rests on the presentation of human life, individual problems, conflicts, and other issues, as reflected by the poet, apart from the aesthetic dimension, i.e., the linguistic side. However, the literary framework is determined also by the physical features, and those are exactly those examined by the scientists in their research. However, we should not ignore some of the essential differences either, because literature addresses many of the intangible aspects in life, such as love (Gottfried von Strassburg's Tristan and Isolde, ca 1210) and death (Johann von Tepl, The Plowman, ca. 1400). Dante's Divina 
Commedia (completed ca. 1320) offers fundamental insights into the human pathway through hell and purgatory toward heaven, with the pilgrim led by his ancient guide Virgil, and later by his beloved, Beatrice. There are many trails in human life, some of which take the individual straight to the goal, whereas others misdirect the protagonist and leave him/her stranded (Classen 2021c).

\subsection{Sir Gawain and the Green Knight}

One of the best illustrations for this would be the anonymous alliterative Middle English romance Sir Gawain and the Green Knight (ca. 1370; Burrow 1977), predicated on an uncanny decapitation game arranged by the Green Knight. Research has already discussed this narrative from many different perspectives, but here I would like to illustrate briefly how we can tease more meaning out of it in a transdisciplinary fashion. The Green Knight, equipped with magical powers, allows his opponent to chop off his head, and then demands that he will the right to do this as well to his opponent. Sir Gawain experiences much fear, horror, and humiliation, but he does not die either. The Green Knight only pretends to hack at his neck and thus tests the young man's resolve, strength, and resilience, a standard feature of much of medieval and early modern literature. At the end, he laughs it all off, whereas Gawain returns home deeply ashamed about his minute shortcoming. He is welcomed by King Arthur and his Round Table as their highest role model, and they all wear from then on a green girdle as a sign of humbleness and honor-fundamental issues in world literature and in social conditions at large, whereby the text gains a symbolic significance concerning ethical and moral issues.

Nevertheless, Gawain would have almost been seduced by the wife of Lord Bercilak of Hautdesert, the Green Knight, and at the end betrays the contract with his host because he wants to survive. The latter had set up a wager with him; both would spend their time on their own, Bercilak out hunting, Gawain staying in the castle, and they would exchange their spoils in the evening. While Bercilak kills one particular animal per day (deer-speed; bear-strength; fox-intelligence), all of them representing Gawain's own qualities, the latter is hunted by Bercilak's wife. However, he resists the lady's attempts and accepts only kisses from her, which he can return to the husband in the evening. He thus manages to maintain his honor, except that he accepts at the end a magical belt that would safeguard his life. Magic, eroticism, the basic desire to survive, male competition, and the probing of an individual's skills and qualities intimately intertwine with each other.

He does not hand over the belt to Bercilak and keeps it hidden because he wants to survive the decapitation game. However, at the end, he feels deeply ashamed about having kept the gift of the green girdle from Bercilak, who knew all about it. The Green Knight therefore cuts his neck with his axe, but he does not kill him; instead, he only laughs about the entire situation and lets Gawain return home, who then wears the green belt as a sign of his shortcoming, more a marker of his honor than of his shame (Sir Gawain and the Green Knight [1997] 1999, ed. and trans. by Vantuono, rev. ed., for some recent scholarship, see Burrow 1977; Howard and Zacher 1968; Putter 1996; Brewer and Gibson 1997; Hatt 2015).

We certainly recognize the need to examine this alliterative romance from a literary perspective, but it also requires close attention to matters such as ethics, morality, symbolism, philosophy, and religion. While the use of magic clearly falls into the category of imagination, the real issues in Sir Gawain and the Green Knight pertain to the quest for personal, subjective integrity, individuality, honor, and ethical principles, i.e., the personal standing within society, that is, one's privileges and responsibilities. We could easily go much more into depth when analyzing this well-known alliterative romance, just as in the case of all other literary examples mentioned above and discussed also below but suffice it here to observe only the extent to which the literary examination quickly leads over to many different aspects determining an individual's existence, both then and today. Honor, above all, proves to be the key element without which no character can survive, at least with self-respect and social esteem, which many representatives of the genre of heroic epics would also confirm. 


\subsection{Conclusions}

To wrap up the discussion of this and the other previous examples, they all illustrate the intangible but fundamental values and ideals undergirding human existence, transcending its purely material conditions. The literary discourse provides the critical framework to come to terms with them and to explore their relevance and meaning. Transdisciplinarity hence offers truly workable avenues into these phenomena because philosophy, sociology, anthropology, and religion would certainly be essentially important hermeneutic tools in coming to terms with those topics as addressed in these medieval narratives. The true value of Sir Gawain and the Green Knight or of Wolfram von Eschenbach's Parzival does not only rest in their high literary quality, as confirmed by many decades of intense scholarly research. What makes these texts works of timeless value is the fact that their authors address universal concerns that will never go away and must be dealt with by every human being as part of his/her growing up and living within larger society. We can reach exactly the same insights when we turn our attention to 'classical' and innovative works composed in other continents and at other times. Our central point is not supposed to be Eurocentric, but global, underscoring the great potential of literature at large to help people comprehending themselves and their world in all of the complexities every society has to cope with.

\section{Mysticism}

Mystical literature (Hildegard of Bingen, Mechthild of Magdeburg, Catharine of Siena, Brigitte of Sweden, Julian of Norwich, Margery Kempe, etc.) appears even further removed from the science field, but both religious and literary scholars, along with those working in the areas of feminism and gender, would be most welcome contributors to the further investigation of this unique late medieval phenomenon. This also opens the perspective toward even more complicated questions as to what we would define as 'literary' and what as 'non-literary', which thus would entail the knotty problem of how we would specify a field such as German Studies more narrowly.

Focusing on the Middle Ages, we might face fewer challenges than in modernity because pure fiction was hardly ever produced at that time. In the early period, every written document, including leechbooks, lawbooks, charms, recipes, etc., is today acknowledged as relevant for Old English or Old High German literature. The high medieval period witnessed the emergence of the Arthurian, Grail, and Tristan romances, more resolutely predicated on the notion of 'fiction' (Haug 1985). However, already in the late Middle Ages, the notion of literature expanded again, with the appearance of countless religious texts, letters, scientific treatises, chronicles, guidebooks, philosophical essays, etc., which would tantalize anyone trying to categorize cleanly fictional and non-fictional texts as genuinely belonging to the field of the humanities and the sciences, respectively. The famous reference work for medieval German literature, Die deutsche Literatur des Mittelalters: Verfasserlexikon (Ruh et al. 1977-2008, vol. 14), endeavors to be as inclusive as possible, laying the groundwork for transdisciplinarity per se.

\section{Philosophy, Theology, and Literature}

St. Augustine and Boethius: Late Antique Sources as Inspiration for Today and Tomorrow

Another intriguing example would be the deep impact of ancient and medieval philosophical texts throughout the entire pre-modern period, as reflected by countless literary examples. For instance, to read medieval courtly romances or verse narratives without the awareness of or familiarity with Boethius's De Consolatione Philosophiae (ca. 525) would not do real justice to the phenomenon itself (Boethius 2001; for critical studies, see, for instance, Gibson 1981; McInerny 1992; Gruber 1978; Marenbon 2004, 2009; cf. also Glei 2010; Classen 2018a). Boethius formulated, after all, the fundamental concept of how to search for true happiness in a philosophical sense, far beyond our material limitations. He did not dismiss worldly sources entirely, but relegated them to the purview of Fortune, 
which, by its own properties, is constantly changing. Hence, neither political power, wealth, or honor would remain forever; true happiness would rest only in complete self-sufficiency, which no individual can ever achieve. However, striving toward this self-sufficiency, the absolute good, or independence, would be the natural drive in all human existence, which ultimately entails that there is no real evil, only an aberration of one's mind.

Boethius's teachings, which cannot be summarized here any further, became deeply influential far into the sixteenth and seventeenth centuries and in fact continues to have a deep impact on us today as well (Classen 2018d, 2020f). Coming to terms fully with his works, however, would require the collaboration of philologists, theologians, philosophers, psychologists, and historians, a task that still has to be achieved.

Similarly, the influence of the Church Father Augustine, Bishop of Hippo (354-430), and many other theologians on religious and courtly literature, and hence on Christianity at large, cannot be underestimated, offering the essential intellectual, moral, and ethical framework upon which the entire Catholic Church was built. However, it would be shortsighted once again to approach his writings, such as his Confessions or his City of God, only from a theological point of view. Instead, Augustine profoundly explored the human quest for the self and the desire to find the pathway to heaven after death. Apart from the many ethical and religious issues addressed by him, he also offered fundamental insights into the spiritual, psychological, emotional, and idealistic elements determining human life (Battenhouse 1955; Quinn 2002 for an excellent survey, introduction, and bibliography, see https:/ / en.wikipedia.org/wiki/Augustine_of_Hippo; accessed on 2 August 2021).

It would not be possible here to identify fully any particular passage in Augustine's massive œuvre, but a few short quotes can illustrate what universal insights he formulated and left for posterity: "And men go abroad to admire the heights of mountains, the mighty waves of the sea, the broad tides of rivers, the compass of the ocean, and the circuits of the stars, yet pass over the mystery of themselves without a thought" (Confessions). "The world is a book, and those who don't travel only read one page". "Miracles are not contrary to nature but only contrary to what we know about nature". Or: "Some people, in order to discover God, read books. But there is a great book: the very appearance of created things. Look above you! Look below you! Read it. God, whom you want to discover, never wrote that book with ink. Instead, He set before your eyes the things that He had made. Can you ask for a louder voice than that?" (https:/ / www.goodreads.com/author/quotes/6819578. Augustine_of_Hippo; accessed on 2 August 2021; for a selection with solid references, see: https: / / en.wikiquote.org/wiki/Augustine_of_Hippo; accessed on 2 August 2021).

In short, the study of late Antiquity and the Middle Ages, like other cultural periods, requires, eo ipso, a transdisciplinary approach to do justice to the complex of influences, sources, interactions, debates, and translations constantly at play at that time (English 1995). If we keep in mind, for instance, the degree to which medieval theologians argued controversially, up to a point of charging each other of having committed heresy (see, e.g., Peter Abelard, d. 1142, or Meister Eckhart [ca. 1260-1328]), we face here a large body of writings that offer a treasure of ideas, concepts, notions, analyses, and interpretations, all addressing, of course, the most abstract and virtually ineffable phenomena, that is, the relationship between the human being and the divine, the matter of faith, the role of people within society and nature, the experience of love, and the question of death.

\section{Hrotsvit of Gandersheim and Herrad of Hohenheim}

Even though most of the known poets from the pre-modern period were not universitytrained (which changed considerably in the fifteenth century), we can be certain that they were deeply informed by the double-concept of the trivium and the quadrivium, as best illustrated by the tenth-century playwright and author of religious tales, Hrotsvit of Gandersheim, and the twelfth-century Herrad of Hohenheim (Hortus deliciarum). While the first, for instance, strategically incorporated rather complex mathematical concepts in her play Sapientia (https:/ / en.wikisource.org/wiki/Plays_of_Roswitha_(1923)/Sapientia; 
accessed on 2 August 2021; Classen 2021b), the latter outlined the basic principles of the seven liberal arts in her text (Griffiths 2007; Heinzer 2016).

\section{Gottfried von Straßburg}

Similarly, Gottfried von Straßburg, poet of the famous Tristan und Isolde (ca. 1210), has often been identified as highly learned, as a true representative of the Renaissance of the Twelfth Century, incorporating in a highly sophisticated manner the finest learning of his time into his romance dealing with the love between these two young people (Jaeger 1977). In order to understand fully the deepest epistemological levels in this text, scholars would need to draw from the history of philosophy, music, architecture (the love cave), and religion but then also linguistics (Tristan as a polyglot), communication (private language of the lovers versus the public language of the court), and law (Isolde's ordeal). Moreover, all those partial elements ultimately contribute to the global ideal hidden behind the narrative itself, the dream of the erotic utopia that Tristan and Isolde achieve for a short moment after having been expelled from King Mark's court. They enjoy each other for some time, freed from all cares about their basic nourishment by telling each other stories, singing songs, and going hunting for entertainment, though without making much noise (even the dog is trained to repress its barking), but, as in all utopias, their time there is limited because they need the contact with human society, identified here with the term 'êre' (honor) (Gottfried on von Strassburg 1980; for an online English translation, see https:/ / www.poetryintranslation.com/PITBR/German/TristanPartXI.php\#anchor_ Toc27675799; accessed on 2 August 2021; as to the concept of utopia here, see Tomasek 1985). Perhaps more than most other medieval authors of courtly romances, Gottfried incorporated profound reflections on music, languages, medicine, politics, law, ethics, and, of course, love, which makes it almost impossible for one scholar alone to develop a fully fledged interpretation (Tomasek 2007). Human life, and hence the humanities, is the result of countless sources, and only a broad-range of approaches to this phenomenon allows for a full understanding of who we are, here determined through the protagonists' absolute need to be integrated into society with all of its complexities.

\section{Fortunatus}

We could also draw from many late medieval texts, such as the anonymous Fortunatus (printed in 1509), in order to realize how much this novel would need to be interpreted from a transdisciplinary perspective, including economics (mercantile activities, global trade), history and religion (political structures, legal systems, travel, pilgrimage), anthropology (encounter between Christians and Muslims), and geography (exploration of Europe and the Middle East). Intriguingly, the anonymous poet also comments once on the difficulties that make it virtually impossible to travel to India and the various reasons why Indians would not show any interest in making their way to cold and hostile Europe (Müller 1990, pp. 385-585; cf. Classen [1995] 1999, pp. 163-83).

The literary analysis thus immediately leads over to anthropological, ethnological, and xenological considerations, and the episodes in which Fortunatus enjoys good relationships with the Egyptian Sultan in Alexandria certainly invite comments about inter-religious issues in the early modern age. Similarly, the narrative provides significant insights into late medieval travel experiences, global awareness, political and legal structures in various countries, and the growing importance of money as the universal currency for all trade. The protagonist miraculously receives as a gift from Fortuna a purse that is always inexhaustible, which makes Fortunatus independently wealthy. Later, he steals a magical cap from the Sultan that allows him to be transported to anywhere in the world as soon as a wish has been formulated. Hence, we recognize here an important literary document mirroring the emergence of modern travel and of the global market (Classen 2020a).

While studying this late medieval (or even early) modern novel, the focus would still remain on the literary dimension, but the critical questions that need to be raised in the interpretation certainly go far beyond the traditional philological ones usually raised by 
German studies scholars. In fact, this early modern novel provides valuable comments about a wide range of social, ethical, economic, and other issues and could thus be used by researchers working in their respective fields when they are in need of narrative data from that early period. Transdisciplinarity thus offers itself as a new platform where the fictional text emerges as a valuable resource for a variety of critical inquiries far beyond the usual humanities-specific criteria. For instance, examining Fortunatus in light of what we know about monetary politics, mercantile structures, international relations during the late Middle Ages, and interreligious dialogues would allow us to achieve a new epistemic level of considerable relevance.

\section{Hermann Hesse-A Modern Voice Inspired by the Middle Ages}

Finally, let me conclude with a brief reference to a most remarkable literary example from the twentieth century in which transdisciplinarity was already fully at play, with the author outlining in concrete terms how this complex approach to humanist epistemology could be realized. In 1946, the German author Hermann Hesse won the Nobel Prize for Literature as a reward for his monumental novel Das Glasperlenspiel (Hesse [1943] 1969). While it would not be possible or necessary here to summarize its plot briefly, the key component consists of a game that is performed by the Magister Ludi, the head of an intellectual, sort of monastic community, a game that is then copied by the members of the entire institution in their effort to glorify the most ethereal and intellectual operations possible.

The ideal glass bead game consists of a combination of various, rather disparate disciplines, such as music, Chinese yoga, and mathematics, very much in the vein of the medieval and ancient-classical liberal arts. As the narrator explains early on:

We have approached the sources from which our modern concept of culture sprang. One of the chief of these was the most recent of the scholarly disciplines, the history of music and the aesthetics of music. Another was the great advance in mathematics that soon followed. To these was added a sprinkling of the wisdom of the Journeyers to the East and, closely related to the new conception and interpretation of music, that courageous new attitude, compounded of serenity and resignation, toward the aging of cultures (20).

And:

It was at this point that Joculator Basiliensis applied himself to the problem. He invented for the Glass Bead Game the principles of a new language, a language of symbols and formulas, in which mathematics and music played an equal part, so that it became possible to combine astronomical and musical formulas, to reduce mathematics and music to a common denominator, as it were. Although what he did was by no means conclusive, this unknown man from Basel certainly laid the foundations for all that came later in the history of our beloved Game (26).

Specific details about the glass bead game are not really provided, but it is clear that it is predicated on ingenious combinations of different modes of cultural, linguistic, and artistic expression, based on music, expanded by mathematics, and crowned by Chinese writing and yoga.

We might call this game a perfect example of transdisciplinarity, but we also have to keep in mind that the protagonist Knecht, after having created his own glass bead game, abdicates from his role of the "magister ludi", leaves the intellectual province of Castalia, tries his hands at practical education in the outside world, and yet then drowns in this effort when he attempts to follow his new disciple Tito in a swimming contest in an icy mountain lake. However, as Hesse also indicates, this death leaves a deep impact on the young man and in fact transforms him profoundly.

Hesse's novel represents a curious case of a literary utopia, which fails, like all others do, but it also signals that true intellectuals are not discipline-bound and can achieve mastery in various fields of human endeavor. Our work in the humanities would be 
equally best served with a solid openness toward other disciplines, integrating their insights, analytic tools, and also data for an innovative, still solidly text-based analysis. The results of such new research should hence become useful for scholars in other disciplines, especially when the larger issues prove to be thorny, complex, esoteric, or ineffable, such as love, the quest for God, the meaning of death, or the purpose of life (Molkow 2021).

\section{Conclusions}

Nevertheless, transdisciplinarity will not be achieved easily, although we see already productive efforts, such as in the areas of medical humanities, ecocritism and ecopoetry, or humanist anthropology. From the literary perspective, nothing can be more welcome than the contributions from art history, philosophy, history, religion, architecture, and archaeology to the critical examination of fictional texts, such as Parzival, Sir Gawain and the Green Knight, Divina Commedia, The Plowman, or Mort d'Artur. In fact, by means of transdisciplinarity, we might gain a new litmus test regarding the quality of a literary text (or work of art), considering its openness toward new methodological approaches and interpretations. Not every medieval poem or romance would lend itself easily to this kind of new research, but many can be interpreted much more profoundly by means of transdisciplinarity. By the same token, much research in philosophy, anthropology, archeology, virology, medicine, theology, ethics, and economics, for instance, can here find most valuable source texts for new data mining.

Hence, what the concept of transdisciplinarity would really entail would be a close collaboration of scholars and scientists from a variety of disciplines who contribute to the investigation of one specific text or topic, either using scientific data to confirm or illuminate aspects addressed in the narrative, play, or poem, or to gain insights about early concepts about scientific phenomena as mirrored already by the writer or poet.

Maybe the most appropriate text to confirm these theoretical reflections would be, briefly moving into the early modern age, the famous ode "Frühlingsfeier" (Celebration of Spring), by Friedrich Gottlieb Klopstock (1724-1803), published in 1759, in which the famous poet combines the latest scientific understanding of the cosmos with his religious vision and celebration of the glory of God. I conclude this study by quoting just the first few stanzas, which would require, to do them full justice, intimate understanding of cosmology, astronomy, the Christian religion, the classical ode, and the history of German literature of the era of Empfindsamkeit (piety and emotions):

Nicht in den Ocean

Der Welten alle

Will ich mich stürzen!

Nicht schweben, wo die ersten Erschafnen,

Wo die Jubelchöre der Söhne des Lichts

Anbeten, tief anbeten,

Und in Entzückung vergehn!

Nur um den Tropfen am Eimer,

Um die Erde nur, will ich schweben,

Und anbeten!

Halleluja! Halleluja!

Auch der Tropfen am Eimer

Rann aus der Hand des Allmächtigen!

Da aus der Hand des Allmächtigen

Die grössern Erden quollen,

Da die Ströme des Lichts

Rauschten, und Orionen wurden;

Da rann der Tropfen

Aus der Hand des Allmächtigen!

Wer sind die tausendmal tausend,
No, not into the ocean

of all the worlds

do I want to throw myself!

Not hover where the first created ones, where the jubilating choirs, the sons of light pray in deep devotion, and dissolve in delight!

Only around the drop at the bucket

around the Earth only, do I want to hover, and pray to Him!

Hallelujah, Hallelujah!

Even the drop at the bucket

flowed out of the Almighty's hand!

When out of the Almighty's hand

the greater worlds welled up,

when the floods of light

rushed and Orion was created;

at that moment the drop

flowed out of the Almighty's hand!

Who are the thousand times thousands, 
Die myriadenmal hundert tausend,

Die den Tropfen bewohnen?

Und bewohnten?

Wer bin ich?

Halleluja dem Schaffenden!

Mehr, als die Erden, die quollen!

Mehr, als die Orionen,

Die aus Strahlen zusammenströmten!

(http:/ / users.ox.ac.uk/ spet0201/hypertexts/klopstock.html; accessed on 2 August 2021; my translation; cf. also Richter 1972).

the myriad time hundred thousands, and inhabited it in the past?

Who am I?

Hallelujah to the Creator!

More than the earths that welled!

More than the Orions,

which flowed together out of beams of light! who inhabit the drop?

If we think about it carefully and with an open mind, literature is not simply an aesthetic experience; instead, it proves to be the platform for the discussion of all human issues, needs, and desires. Here, we find healing, promises, ideals, insights, new ways of thinking, and a means to achieve justice. As Simon Gikandi powerfully stated in his address to the MLA in 2020:

Amid the violence of the modern, this thing called literature has made it possible for many of us to recover the sensation of life and to yearn for valuesincluding justice and beauty-that help us counter the logic of domination". (Gikandi 2020, p. 856)

Considering also the critical need for humanity to find its way through and out of the Anthropocene in order to survive here on the planet earth, and keeping in mind the already existing force of artificial intelligence which might, in some sense, ultimately replace human intelligence, literature offers intriguing perspectives of a utopian kind that invite colleagues from many different disciplines to respond to the calls for action and to work toward a better future (esboços: Histórias em Contextos Globais 2020). As Piotr Bołtuć emphasizes, the future might require a close interconnectivity between humans and AI, a large challenge especially in light of fundamental ethical, moral, and spiritual issues that determine humanity at large. Could we then still claim to be human under those circumstances? We still enjoy our freedom, but once algorithms take over all control, even the best efforts by humanists, philosophers, or religious scholars will be of no use. Hence, the clarion call right now to establish global networks, to collaborate as much as possible, and to grasp the meaning of literature as a narrative medium connecting us all in a powerful alliance against the machine.

At this point, however, transdisciplinary approaches still face large challenges in opening up the perspectives toward a non-Eurocentric perspective, acknowledging, as recent research has increasingly endeavored, the necessity in all humanistic and scientific research to recognize global perspectives, and the constant give and take in economic, political, religious, literary, and artistic terms (Heng and Ramey 2014; Heng 2015, 2018). Nevertheless, interdisciplinary methods at least within the humanities have already yielded excellent new insights (Classen 2013); the current task consists of reaching out across academic demarcations and challenging traditional administrative structures that may serve political and economic interests but certainly do not promote the innovative research of the future.

Funding: This research received no external funding.

Conflicts of Interest: The author declares no conflict of interest.

\section{Note}

1 See the organization "Partners That Heal" operating in Arizona hospitals, bringing theater to patients, producing an amazing transformation of the patients' attitude and mind-set and thus also much improved healing conditions. https://www. phoenixtheatre.com/engage-learn/partners-that-heal; accessed on 2 August 2021. Cf. also Watson (2011). See also Hall (2015). 


\section{References}

Abba, A. Abba, and Nkiru D. Onyemachi. 2020. Weeping in the Face of Fortune: Eco-Alienation in the Niger-Delta Ecopoetics. Humanities 9: 54. [CrossRef]

Aberth, John. 2011. Plagues in World History. Exploring World History. Lanham: Rowman \& Littlefield.

Aberth, John. 2013. An Environmental History of the Middle Ages: The Crucible of Nature. London and New York: Routledge.

Barker, Hannah. 2019. That Most Precious Merchandise: The Mediterranean Trade in Black Sea Slaves, 1260-1500. The Middle Ages Series; Philadelphia: University of Pennsylvania Press.

Battenhouse, Roy W., ed. 1955. A Companion to the Study of St. Augustine. New York: Oxford University Press.

Bauch, Martin, and Gerrit Jasper Schenk, eds. 2020. The Crisis of the 14th Century: Teleconnections between Environmental and Societal Change? Berlin and Boston: Walter de Gruyter.

Bennassar, Bartolomé, ed. 1996. Les catastrophes naturelles dans l'Europe médiévale et moderne: Actes des XVes Journées Internationales d'Histoire de l'Abbaye de Flaran, 10, 11 et 12 Septembre 1993. Flaran. Toulouse: Presses Université du Mirail, p. 15.

Boccaccio, Giovanni. 1995. The Decameron, 2nd ed. Translated, Intro and Notes by G. H. McWilliam. London: Penguin. First published 1972.

Bod, Rens. 2014. A New History of the Humanities. Oxford: Oxford University Press.

Boethius. 2001. Consolation of Philosophy. Translated, Intro and Notes by Joel C. Relihan. Indianapolis and Cambridge: Hackett Publishing.

Bołtuć, Piotr. 2021. Trans-Humanities as the Pinnacle and a Bridge. Humanities. forthcoming.

Brewer, Derek, and Jonathan Gibson, eds. 1997. A Companion to the Gawain-Poet. Arthurian Studies. Cambridge: D. S. Brewer, p. 38.

Burrow, John Anthony. 1977. A Reading of Sir Gawain and the Green Knight. London, Henley and Boston: Routledge \& Kegan Paul.

Camenisch, Chantal. 2015. Witterung, Getreidepreise und Subsistenzkrisen in den Burgundischen Niederlanden im ausgehenden Mittelalter. Wirtschafts-, Sozial- und Umweltgeschichte. Basel: Schwabe, p. 5.

Campbell, Bruce M. S. 2010. Nature as Historical Protagonist: Environment and Society in Pre-Industrial England. The Economic History Review 63: 281-314. [CrossRef]

Campbell, Bruce M. S. 2016. The Great Transition: Climate, Disease and Society in the Late-Medieval World. The 2013 Ellen McArthur Lectures. Cambridge: Cambridge University Press.

Choi, Bernard C. K., and Anita W. P. Pakhave. 2006. Multidisciplinarity, Interdisciplinarity and Transdisciplinarity in Health Research, Services, Education and Policy: 1. Definitions, Objectives, and Evidence of Effectiveness. Clinical and Investigative Medicine 29: 351-64. Available online: https://pubmed.ncbi.nlm.nih.gov/17330451/\#: \{\}:text=Interdisciplinarity \%20analyzes $\% 2 C \%$ 20synthesizes \%20and\%20harmonizes, and\%20transcends\%20their\%20traditional\%20boundaries (accessed on 2 August 2021). [PubMed]

Classen, Albrecht. 1999. The German Volksbuch. A Critical History of a Late-Medieval Genre. Studies in German Language and Literature. Lewiston, Queenston and Lampeter: Edwin Mellen Press, p. 15. First published 1995.

Classen, Albrecht. 1998. Ernst Robert Curtius and the Topos of the Book. The Impact of an Idea on Modern Philological Research. Leuvense Bijdragen 87: 59-78.

Classen, Albrecht, ed. 2010. Handbook of Medieval Studies: Terms-Methods-Trends. Berlin and New York: Walter de Gruyter, vol. 3.

Classen, Albrecht. 2011. Humanities-To Be or Not to Be, That Is the Question. Editorial for the journal Humanities-Open Access Journal. Available online: http:/ / www.mdpi.com/2076-0787/1/1/54 (accessed on 2 August 2021).

Classen, Albrecht, ed. 2013. East Meets West in the Middle Ages and Early Modern Times: Transcultural Experiences in the Premodern World. Fundamentals of Medieval and Early Modern Culture. Berlin and Boston: Walter de Gruyter, p. 14.

Classen, Albrecht, ed. 2014. Mental Health, Spirituality, and Religion in the Middle Ages and Early Modern Age. Fundamentals of Medieval and Early Modern Culture. Berlin and Boston: Walter de Gruyter, p. 15.

Classen, Albrecht. 2018a. Boethius and No End in Sight: The Impact of De consolatione philosophiae on Early Modern German Literature From the Fifteenth Through the Seventeenth Century: Andreas Gryphius and Johann Scheffler (Angelus Silesius). Daphnis 46: 448-66. [CrossRef]

Classen, Albrecht. 2018b. Medieval Transculturality in the Mediterranean from a Literary-Historical Perspective: The Case of Rudolf von Ems's Der guote Gêrhart (ca. 1220-ca. 1250). Journal of Transcultural Medieval Studies 5: 133-60. Available online: https:/ / www.degruyter.com/downloadpdf/j/jtms.2018.5.issue-1/jtms-2018-0006/jtms-2018-0006.pdf (accessed on 2 August 2021). [CrossRef]

Classen, Albrecht. 2018c. Toleration and Tolerance in Medieval and Early Modern European Literature. Routledge Studies in Medieval Literature and Culture. New York and London: Routledge, p. 8.

Classen, Albrecht. 2018d. Waterways as Landmarks, Challenges, and Barriers for Medieval Protagonists: Crossing Rivers as Epistemological Hurdles in Medieval Literature. Amsterdamer Beiträge zur älteren Germanistik 78: 441-67. [CrossRef]

Classen, Albrecht. 2019. The Past as the Key for the Future: Reflections on an Ancient Question. What Does (Medieval) Literature Mean Today in the Twenty-First Century? Athens Journal of Philology 6: 147-70. Available online: https://www.athensjournals.gr/ philology/2019-6-3-1-Classen.pdf (accessed on 2 August 2021). [CrossRef]

Classen, Albrecht. 2020a. The Global World in the Pre-Modern Era: Lessons from the Past for Our Future: With a Focus on the Early Modern Novel Fortunatus (1509). Current Research Journal of Social Sciences and Humanities 3: 152-64. Available online: http:/ /journalofsocialsciences.org/pdf/vol3no2/CRJSSH_Vol03_No2_p_152-164.pdf (accessed on 2 August 2021). [CrossRef] 
Classen, Albrecht. 2020b. Globalism in Medieval Literature? Pre-Modern Perspectives in Poetic Projections: Wolfram von Eschenbach's Parzival, Konrad Fleck's Flore und Blancheflor, and Reinfried von Braunschweig. Athens Journal of Philology 7: 1-29. Available online: https://www.athensjournals.gr/humanities/2021-8-1-1-Classen.pdf (accessed on 2 August 2021).

Classen, Albrecht. 2020c. The Relevance of The Humanities in the Twenty-First Century: Past and Present. Edited by Albrecht Classen. Special Issue of Humanities Open Access. Available online: https://www.mdpi.com/journal/humanities/special_issues/pas_pre (accessed on 2 August 2021).

Classen, Albrecht. 2020d. Religious Toleration in the Middle Ages and Early Modern Age: An Anthology of Literary, Theological, and Philosophical Texts. Berlin: Peter Lang.

Classen, Albrecht. 2020e. Rivers as Critical Boundaries in Wolfram von Eschenbach's Parzival and Titurel: Ecocritical Perspectives in Medieval German Literature. In Reading the Natural World in the Middle Ages and Renaissance: Perceptions of the Environment and Ecology. Edited by Thomas Willard. Arizona Studies in the Middle Ages and Renaissance. Turnhout: Brepols, vol. 46, pp. 21-34.

Classen, Albrecht. 2020f. Literature as a Tool of Epistemology: Medieval Perspectives for Post-Modernity: Or, the Post-Modern World Long Anticipated by the Pre-Modern: Boethius's De consolatione philosophiae, Apollonius of Tyre, Marie de France, and Ulrich Bonerius. New Literaria-An International Journal of Interdisciplinary Studies in Humanities 1: 1-19. Available online: https:/ / newliteraria.com/ (accessed on 2 August 2021).

Classen, Albrecht. 2021a. Freedom, Imprisonment, and Slavery in the Pre-Modern World: Cultural-Historical, Social-Literary, and Theoretical Reflections. Fundamentals of Medieval and Early Modern Culture. Berlin and Boston: Walter de Gruyter, p. 25.

Classen, Albrecht. 2021b. Hrotsvit of Gandersheim. Literary Encyclopedia. Available online: https://www.litencyc.com/php/speople. php?rec=true\&UID=12386 (accessed on 2 August 2021).

Classen, Albrecht. 2021c. Tracking the Trails: Epistemological Explorations, Orientation, and Mapping in Medieval Literature. Routledge Studies in Medieval Literature and Culture. New York and London: Routledge.

Classen, Albrecht. Forthcoming. The Topic of Persia in Medieval Literary Imagination, with a Focus on Middle High German Literature. Ceræ: An Australasian Journal of Medieval and Early Modern Studies.

Clay, Rebecca. 2008. The Corporatization of Higher Education. American Psychological Association 39: 11. Available online: https: / / www.apa.org/monitor / 2008/12/higher-ed\#: \{\}:text=The\%20rise \%20of\%20consumerism\%2C \%20a, and \%20seeking\% 20profit\%2Dmaking\%20opportunities (accessed on 2 August 2021).

Collado Ruano, Javier. 2013. Transdisciplinary Education as Ethic of the Diversity Reform in the World-Society of the 21st Century. Global Education Magazine. Available online: http:/ / www.globaleducationmagazine.com/transdisciplinary-education-ethicdiversity-reform-world-society-21st-century / (accessed on 2 August 2021).

Côté, James, and Anton L. Allahar. 2020. Lowering Higher Education: The Rise of Corporate Universities and the Fall of Liberal Education. Toronto: Toronto University Press.

Curtius, Ernst Robert. 1990. European Literature and the Latin Middle Ages. Translated by Willard A. Trask. Bollingen Series; Princeton: Princeton University Press, p. 36. First published 1948.

Donoghue, Frank. 2008. The Last Professors: The Corporate University and the Fate of the Humanities. New York: Fordham University Press.

Dravet, Florence, Florent Pasquier, Javier Collado, and Gustavo de Castro, eds. 2020. Transdisciplinariedad y Educación del Futuro. Águas Claras: Cátedra UNESCO de Juventud, Educación y Sociedad-Universidad Católica de Brasilia.

Eco, Umberto. 1993. Six Walks in the Fictional Woods. Charles Eliot Norton Lectures. Cambridge: Harvard University Press.

English, Edward D. 1995. Reading and Wisdom: The De doctrina Christiana of Augustine in the Middle Ages. Notre Dame Conferences in Medieval Studies. Notre Dame: University of Notre Dame Press, p. 6.

esboços: Histórias em Contextos Globais. 2020. vol. 27, p. 46. Available online: https://periodicos.ufsc.br/index.php/esbocos/issue/ view/3104 (accessed on 2 August 2021).

Fouquet, Gerhard, and Gabriel Zeilinger. 2011. Katastrophen im Spätmittelalter. Darmstadt and Mainz: Philipp von Zabern.

Gibson, Margaret, ed. 1981. Boethius: His Life, Thought and Influence. Oxford: Basil Blackwell.

Gikandi, Simon. 2020. Literature and the Right to Be Human. PMLA 135: 847-58.

Glei, Reinhold, ed. 2010. Boethius Christianus? Transformationen der Consolatio Philosophiae in Mittelalter und Früher Neuzeit. Berlin and New York: Walter de Gruyter.

Grafton, Anthony, and Lisa Jardine. 1987. From Humanism to the Humanities: The Institutionalizing of the Liberal Arts in Fifteenth-and Sixteenth-Century Europe. Boston: Harvard University Press.

Green, Monica H., ed. 2015. Pandemic Disease in the Medieval World: Rethinking the Black Death. The Medieval Globe. Leeds: Arc Humanities Press, p. 1.

Griffiths, Fiona. 2007. The Garden of Delights: Reform and Renaissance for Women in the Twelfth Century. The Middle Ages Series; Philadelphia: University of Pennsylvania Press.

Groos, Arthur. 1995. Romancing the Grail: Genre, Science, and Quest in Wolfram's Parzival. Ithaca and London: Cornell University Press.

Gruber, Joachim. 1978. Kommentar zu Boethius De Consolatione Philosophiae. Texte und Kommentare-eine altertumswissenschaftliche Reihe. Berlin and New York: Walter de Gruyter, p. 9.

Hall, Pippa. 2015. Medicine \& Humanities at University of Ottawa's Faculty of Medicine: Developing a curriculum for our undergraduate medical education program. Chronic Disease 5: 58. Available online: https://uottawa.scholarsportal.info/ottawa/ index.php/uojm-jmuo/issue/view /232/26 (accessed on 2 August 2021). 
Hamilton, Allan J. 2008. The Scalpel and the Soul: Encounters with Surgery, the Supernatural, and the Healing Power of Hope. New York: Jeremy P. Tarcher/Putnam.

Harrison, Freya, and Erin Connelly. 2020. Could Medieval Medicine Help the Fight Against Antimicrobial Resistance? In Making the Medieval Relevant: How Medieval Studies Contribute to Improving Our Understanding of the Present. Edited by Chris Jones, Conor Kostick and Klaus Oschema. Berlin and Boston: Walter de Gruyter, pp. 113-34.

Hatt, Cecilia A. 2015. God and the Gawain-Poet: Theology and Genre in Pearl, Cleanness, Patience and Sir Gawain and the Green Knight. Cambridge: D. S. Brewer.

Haug, Walter. 1985. Literaturtheorie im deutschen Mittelalter: Von den Anfängen bis zum Ende des 13. Jahrhunderts. Darmstadt: Wissenschaftliche Buchgesellschaft.

Heinzer, Felix. 2016. Wissen und Weisheit im Frauenkloster. Der Hortus Deliciarum Herrads von Hohenburg als Zeugnis hochmittelalterlicher Bildungsgeschichte. In Schule und Bildung am Oberrhein in Mittelalter und Neuzeit. Edited by Ursula Huggle and Heinz Krieg. Forschungen zur oberrheinischen Landesgeschichte. Freiburg: Karl Alber, vol. 60, pp. 11-24.

Heng, Geraldine. 2015. Reinventing Race, Colonization, and Globalisms across Deep Time: Lessons from the Longue Durée. PMLA 130: 358-66. [CrossRef]

Heng, Geraldine. 2018. The Invention of Race in the European Middle Ages. Cambridge: Cambridge University Press.

Heng, Geraldine, and Lynne Ramey. 2014. 'Early Globalities, Global Literatures: Introducing a Special Issue on the Global Middle Ages'. Literature Compass, 1-6. [CrossRef]

Hesse, Hermann. 1969. Magister Ludi The Glass Bead. Game. Translated by Richard, and Clara Winston. New York: Holt, Rinehart and Winston. First published 1943. (In German: Das Glasperlenspiel).

Holmes, Catherine, and Naomi Standen, eds. 2018. The Global Middle Ages. Past\&Present. Supplement, New Series. Oxford: Oxford University Press, p. 13.

Horden, Peregrine, and Nicholas Purcell. 2000. The Corrupting Sea: A Study of Mediterranean History. Oxford: Blackwell.

Horden, Peregrine, and Nicholas Purcell. 2020. The Boundless Sea: Writing Mediterranean History. Variorum Collected Studies. London: Routledge, p. 1083.

Howard, Donald R., and Christian Zacher, eds. 1968. Critical Studies of Sir Gawain and the Green Knight. Notre Dame and London: University of Notre Dame Press.

Jaeger, Stephen C. 1977. Medieval Humanism in Gottfried von Strassburg's Tristan und Isolde. Germanische Bibliothek/3: Untersuchungen und Einzeldarstellungen. Heidelberg: Universitätsverlag.

Jankrift, Kay Peter. 2003. Brände, Stürme, Hungersnöte: Katastrophen in der mittelalterlichen Lebenswelt. Ostfildern: Thorbecke.

Johns-Putra, Adeline, ed. 2019. Climate and Literature. Cambridge Critical Concepts. Cambridge: Cambridge University Press.

Jones, Chris, Conor Kostick, and Klaus Oschema, eds. 2020. Making the Medieval Relevant: How Medieval Studies Contribute to Improving Our Understanding of the Present. Berlin and Boston: Walter de Gruyter.

Jost, Jean E. 2016. The Effects of the Black Death: The Plague in Fourteenth-Century Religion, Literature, and Art. In Death in the Middle Ages and Early Modern Times: The Material and Spiritual Conditions of the Culture of Death. Edited by Albrecht Classen. Fundamentals of Medieval and Early Modern Culture. Berlin and Boston: Walter de Gruyter, vol. 16, pp. 193-228.

Koenigberg, Richard A. n.d. Awakening from the Nightmare of History: Psychological Interpretation of War and Genocide. Available online: https: / / www.libraryofsocialscience.com/essays/koenigsberg-awakening/ (accessed on 2 August 2021).

Lazzeretti, L., F. Capone, A. Caloffi, and S. R. Sedita. 2019. Rethinking Clusters. Towards a New Research Agenda for Cluster Research. European Planning Studies 27: 1879-1903. [CrossRef]

Mallesh Reddy, B., S. N. Shende, and D. Premila Swami, eds. 2021. Environmental Protection and Its Reflection in Literature. Hamburg: Tredition.

Marenbon, John. 2004. Boethius. Oxford: Oxford University Press.

Marenbon, John, ed. 2009. The Cambridge Companion to Boethius. Cambridge: Cambridge University Press.

Mas i Forners, Antoni. 2005. Esclaus i catalans: Esclavitud i segregació a Mallorca durant els segles XIV i XV. Trafalempa. Palma: Lleonard Muntaner, p. 1.

McInerny, Ralph. 1992. Boethius, Medieval Philosophers. Edited by Jeremiah Hackett. Dictionary of Literary Biography. Detroit and London: Gale Research, vol. 115, pp. 110-17.

Molkow, Wolfgang. 2021. Wenn die Musik nicht wär': Ernst von Wolzogen "Der Kraft-Mayr", Franz Werfel "Verdi-Roman der Oper", Hermann Hesse "Das Glasperlenspiel". Musik im Roman. Hofheim am Taunus: Wolke, p. 3.

Müller, Jan-Dirk, ed. 1990. Romane des 15. und 16. Jahrhunderts. Bibliothek der frühen Neuzeit. Frankfurt: Deutscher Klassiker Verlag, p. 1.

Murphy, G. Ronald S. J. 2006. Gemstone of Paradise: The Holy Grail in Wolfram's Parzival. Oxford: Oxford University Press.

Nardizzi, Vin, and Tiffany Jo Werth. 2019. Premodern Ecologies in the Modern Literary Imagination. Toronto, Buffalo and London: University of Toronto Press.

Putter, Ad. 1996. An Introduction to the Gawain-Poet. Longman Medieval and Renaissance Library. London and New York: Longman. Quinn, John M. 2002. A Companion to the Confessions of St. Augustine. New York: Peter Lang.

Refsum Jensenius, Alexander. 2012. Disciplinarities: Intra, Cross, Multi, Inter, Trans. Available online: https://www.arj.no/2012/03/ 12/disciplinarities-2/ (accessed on 2 August 2021). 
Richter, Karl. 1972. Literatur und Naturwissenschaft: Eine Studie zur Lyrik der Aufklärung. Theorie und Geschichte der Literatur und der schönen Künste. Munich: Wilhelm Fink, p. 19.

Rousseau, David, Jennifer Wilby, Julie Billingham, and Stefan Blachfellner. 2018. General Systemology: Transdisciplinarity for Discovery, Insight and Innovation. Translational Systems Sciences. Singapore: Springer, p. 13.

Rudolf von Ems, Albrecht Classen. 2016. An English Translation of Rudolf von Ems's Der guote Gêrhart. Newcastle upon Tyne: Cambridge Scholars Press.

Ruh, Kurt, Gundolf Keil, Werner Schröder, Burghart Wachinger, and Franz Josef Worstbrock. 1977-2008. Die deutsche Literatur des Mittelalters: Verfasserlexikon. Berlin and New York: Walter de Gruyter, vol. 14.

Schmitz-Esser, Romedio. 2020. The Corpse in the Middle Ages: Embalming, Cremating, and the Cultural Construction of the Dead Body. Translated by Albrecht Classen, and Carolyn Radtke. Turnhout: Brepols.

Shamoo, Adil, and David B. Resnik. 2015. Responsible Conduct of Research, 3rd ed. New York: Oxford University Press.

Sir Gawain and the Green Knight, 1999, Rev. ed. Translated and Edited by William Vantuono. Notre Dame: University of Notre Dame Press. First published 1997.

Stimpson, Catharine R. 2009. Review of Frank Donoghue AAUP, January-February. Available online: https://www.aaup.org/article/ apocalypse\#.X-0F_dhKg2w (accessed on 2 August 2021).

Tomasek, Tomas. 1985. Die Utopie im Tristan Gotfrids von Strassburg. Hermaea, Neue Folge. Tübingen: Max Niemeyer, p. 49.

Tomasek, Tomas. 2007. Gottfried von Straßburg. Stuttgart: Philipp Reclam Jun.

Tubbs, Nigel. 2014. Philosophy and Modern Liberal Arts Education: Freedom is to Learn. Houndmills, Basingstoke and Hampshire: Palgrave Macmillan.

Vargas Llosa, Mario. 1990. La Verdad de las Mentiras: Ensayos Sobre Literatura. Biblioteca Breve. Barcelona: Seix Barral.

von Eschenbach, Wolfram. 1998. Parzival. Studienausgabe, 2nd ed. Mittelhochdeutscher Text nach der sechsten Ausgabe von Karl Lachmann. Übersetzung von Peter Knecht. Berlin and New York: Walter de Gruyter.

von Eschenbach, Wolfram. 2006. Parzival and Titurel. Translated and Notes by Cyril Edwards. Oxford: Oxford University Press.

Von Sass, Hartmut, ed. 2019. Between/Beyond/Hybrid: New Essays on Transdisciplinarity. Zürich: Diaphanes.

von Strassburg, Gottfried. 1980. Tristan. Translated and Edited by Rüdiger Krohn. Stuttgart: Philipp Reclam Jun.

Wagner, David Leslie. 1983. The Seven Liberal Arts in the Middle Ages. Bloomington: Indiana University Press.

Warren, Michael, ed. 2021. Medieval Weathers: Meteorological Phenomena in Medieval Writing and Culture. Special Issue of Medieval Ecocriticism. Kalamazoo: Medieval Institute Publications, forthcoming.

Watson, Katie. 2011. Serious Play: Teaching Medical Skills with Improvisational Theater Techniques. Academic Medicine 86: 1260-65. [CrossRef] [PubMed]

Willard, Thomas, ed. 2020. Reading the Natural World in the Middle Ages and Renaissance: Perceptions of the Environment and Ecology. Arizona Studies in the Middle Ages and Renaissance. Turnhout: Brepols, p. 46.

Zakaria, Fareed. 2015. In Defense of a Liberal Education. New York: W. W. Norton \& Company. 